\title{
ZNAJOMOŚĆ IDEI GRUP PRODUCENCKICH WŚRÓD UCZNIÓW SZKÓŁ ROLNICZYCH
}

\begin{abstract}
Zarys treści: Celem artykułu jest określenie znajomości idei grup producentów rolnych w Polsce wśród uczniów szkół rolniczych. Pomimo szeregu inicjatyw podejmowanych na rzecz rozwoju grup producenckich, o charakterze promocyjnym czy edukacyjnym, integracja wśród polskich rolników nie jest popularna. Zwrócono uwagę, że tendencja do częstszego integrowania się rolników młodszych i lepiej wykształconych sugeruje, aby zainteresować się systemem kształcenia rolniczego. Stosunkowo dobrze rozbudowana sieć szkół rolniczych stanowi potencjał do upowszechniania idei grup producenckich, jednak w toku badania nie wykazano jednoznacznej zależności pomiędzy działalnością szkół a powstawaniem grup producenckich. Pomimo możliwości realizowania przez szkoły rolnicze modułu edukacyjnego dotyczącego funkcjonowania grup producenckich, znajomość idei wśród uczniów jest słaba.
\end{abstract}

Słowa kluczowe: grupy producentów rolnych, szkoły rolnicze, program nauczania.

\section{Wstęp}

Szkoły na obszarach wiejskich pełnią rolę lokalnych ośrodków rozwoju wsi, są miejscem edukacji, wydarzeń kulturalnych, sportowych czy społecznych. W przypadku szkół rolniczych oczekiwania są jeszcze większe, gdyż od tego typu placówek można wymagać, aby były miejscem upowszechniania postępu rolniczego i szerzenia szeroko pojmowanej innowacyjności, w tym organizacyjnej. Jak zauważa J. Kania (2014) zadaniem uczelni i szkół rolniczych jest systematyczne wzmacnianie systemu wiedzy rolniczej. Jednocześnie w środowisku rolniczym podnosi się zarzut niskiej przydatności wiedzy teoretycznej, rolnicy szczególnie cenią sobie wiadomości praktyczne przydatne w bezpośrednim działaniu (Krzyworzeka 2011).

Jednym z wyzwań jakie nadal stoi przed polskim rolnictwem jest słaba integracja pozioma producentów rolnych. Pomimo upływu już ponad 14 lat od uchwalenia Ustawy o grupach producentów rolnych i ich zwiazkach oraz o zmianie innych ustaw z dnia 15 września 2000 roku (Dz.U., nr 88, poz. 983 ze zm.) oraz możliwości uzyskania szeregu przywilejów wynikających z przynależności do grupy, popularność tego typu działalności jest niezadowalająca. Podej- 
mowane dotychczas działania promujące grupy producentów rolnych można uznać za mało efektywne, gdyż liczba gospodarstw przynależnych do grup nie przekracza $5 \%$ ogółu. Wydaje się, że naturalną grupą docelową działań popularyzujących integrację poziomą rolników jest młodzież szkolna kształcąca się w zawodach rolniczych. Powszechnie wiadomo, że to właśnie ludzie młodzi są bardziej otwarci na zmiany i innowacje (Hamerska, Roczkowska-Chmaj 2008; Kałuża, Ginter 2014). Jak zauważa Z. Kołoszko-Chomentowska (2008) otwartość rolników na zmiany jest skorelowana z ich wykształceniem, osoby o wyższych kwalifikacjach łatwiej je akceptują i jednocześnie chętniej podejmują nowe wyzwania.

Celem opracowania jest określenie stopnia znajomości idei grup producentów rolnych w Polsce wśród uczniów szkół rolniczych. Poznanie stanu wiedzy uczniów w zakresie grup producenckich ma kluczowe znaczenie dla podjęcia decyzji przez instytucje publiczne i organizacje rolnicze o potrzebie upowszechniania integracji poziomej poprzez szkoły rolnicze.

Wykorzystano głównie informacje pochodzące $\mathrm{z}$ badania ankietowego przeprowadzonego w czerwcu 2014 roku wśród uczniów dwóch szkół rolniczych z terenu województwa wielkopolskiego. Szkoły zostały wybrane do badania ankietowego w sposób celowy, skupiono się na obszarze o dużej popularności grup producenckich, gdzie działalność grupowa ma duże tradycje tj. powiaty krotoszyński i ostrowski. Zdecydowano się na celowy wybór szkół, gdyż przewidywano, że wiedza z zakresu grup producenckich wśród uczniów może być na większości obszaru kraju jednakowo niska, a w takiej sytuacji ewentualne zależności najłatwiej byłoby zauważyć w regionie o najwyższym zawansowaniu działań integracyjnych. Dobór respondentów miał charakter losowy, o wypełnienie ankiety zostali poproszeni uczniowie z 9 klas, których numery porządkowe zostały wylosowane $\mathrm{z}$ dziennika klasowego. $\mathrm{W}$ badaniu wzięło udział 185 uczniów klas I-III technikum rolniczego i agrobiznesu.

\section{Szkoły rolnicze w Polsce}

Mianem szkoły rolniczej według Ustawy o systemie oświaty z dnia 7 września 1991 roku (Dz.U., 1991, nr 95, poz. 425) możemy określić szkołę ponadgimnazjalną kształcącą $\mathrm{w}$ zawodach przydatnych dla rolnictwa. Katalog zawodów przydatnych dla rolnictwa podlega zmianom i jest określany w drodze rozporządzenia wydawanego przez ministra właściwego do spraw rolnictwa. Według aktualnie obowiązującego Rozporzadzenia MRiRW z dnia 17 stycznia 2012 roku (Dz.U., 2012, poz. 109) za przydatne w działalności rolniczej uznano 24 zawody, w tym 16 na poziomie technikum. W szkołach rolniczych w 2011 roku kształciło się ponad 78 tys. uczniów, jednak jak zauważa K. Wasilewski (2011) znacząca większość wybiera technika, a w szkołach zawodowych liczba uczniów zapewniła otwarcie zaledwie 9 oddziałów. Szkolnictwo ponadgimna- 
zjalne leży w kompetencji samorządów powiatowych. W przypadku szkół rolniczych najczęściej to jednostki samorządu terytorialnego są organem prowadzącym (293 szkoły). Ze względu na znaczenie szkół rolniczych w rozwoju wsi i rolnictwa 45 placówek jest prowadzonych bezpośrednio przez Ministerstwo Rolnictwa i Rozwoju Wsi.

Szkoły rolnicze możemy uznać za jedno z krytycznych ogniw Systemu Wiedzy Rolniczej i Informacji Rolniczej (Kania 2006), które ma umożliwiać upowszechnianie postępu rolniczego w skali lokalnej, ale przede wszystkim dostarczać podstawowej kadry dla pozostałych elementów tego systemu. Wydaje się, że nabycie wiedzy, umiejętności i właściwych postaw już na etapie szkoły ponadgimnazjalnej ma duże znaczenie dla kreowania zmian w rolnictwie, $\mathrm{w}$ tym upowszechniania idei grup producenckich ze względu, że osoby młode z natury są bardziej otwarte na zmiany i skłonne do ryzyka. Potwierdzają to m.in. badania K. Krzyżanowskiej (2000), według której rolnicy lepiej wykształceni i młodsi chętniej podejmują współpracę w grupie producenckiej.

Dostępność do szkolnictwa może być analizowana w aspekcie społecznym, ekonomicznym czy przestrzennym. Ze względu na dostępność danych, w niniejszym opracowaniu wykorzystano miernik dostępności przestrzennej, obliczany jako liczba szkół na 10000 ha użytków rolniczych. Według J. Dominiak (2012) odniesienie liczby punktów usługowych do powierzchni stanowi bardzo prosty miernik, który pośrednio wskazuje na dystans jaki należy pokonać w celu realizacji usługi. Nieprzypadkowo punktem odniesienia do stosowanych w niniejszym opracowaniu mierników przyjęto powierzchnię użytków rolniczych, gdyż ich obecność jest jednym z najistotniejszych uwarunkowań funkcjonowania rolnictwa. Przeliczając liczbę szkół rolniczych na 10000 ha użytków rolniczych, w 2014 roku uczniowie mieli najłatwiejszy do nich dostęp w województwie opolskim $(0,31)$. Najtrudniejsza sytuacja dotyczy województw świętokrzyskiego i małopolskiego, w przypadku których wskaźnik wynosi odpowiednio 0,07 i 0,12 szkoły na 10000 ha UR (rys. 1). Prawdopodobnie słabe perspektywy rozwoju działalności rolniczej wynikające ze znacznego rozdrobnienia gospodarstw rolnych nie skłaniają młodzieży do kształcenia w zawodach rolniczych, a z uwagi na niską popularność kierunków rolniczych szkoły z nich rezygnują. Jak zauważa K. Wasilewski (2011) zawody rolnicze mają niski prestiż w ocenie młodzieży, jednak decydującą kwestią wpływającą na wybór zawodów pozarolniczych jest pragmatyczne podejście młodzieży, która wybiera kierunki uniwersalne, dające lepsze perspektywy znalezienia pracy, gdyż kierunkowe wykształcenie do prowadzenia niewielkiego gospodarstwa rolnego, niedającego pełnego zatrudnienia wydaje się być zbędne. Dysproporcje pomiędzy regionami są jednak stosunkowo niewielkie i brak jest wyraźnego podziału na obszary o mniejszej i większej liczbie szkół rolniczych, które można by tłumaczyć np. uwarunkowaniami historycznymi. Należy zaznaczyć, że wysoki poziom kultury rolnej jaki dotyczy województw wielkopolskiego czy dolnośląskiego nie zawsze jest powiązany z najlepszą dostępnością do szkół rolniczych. 


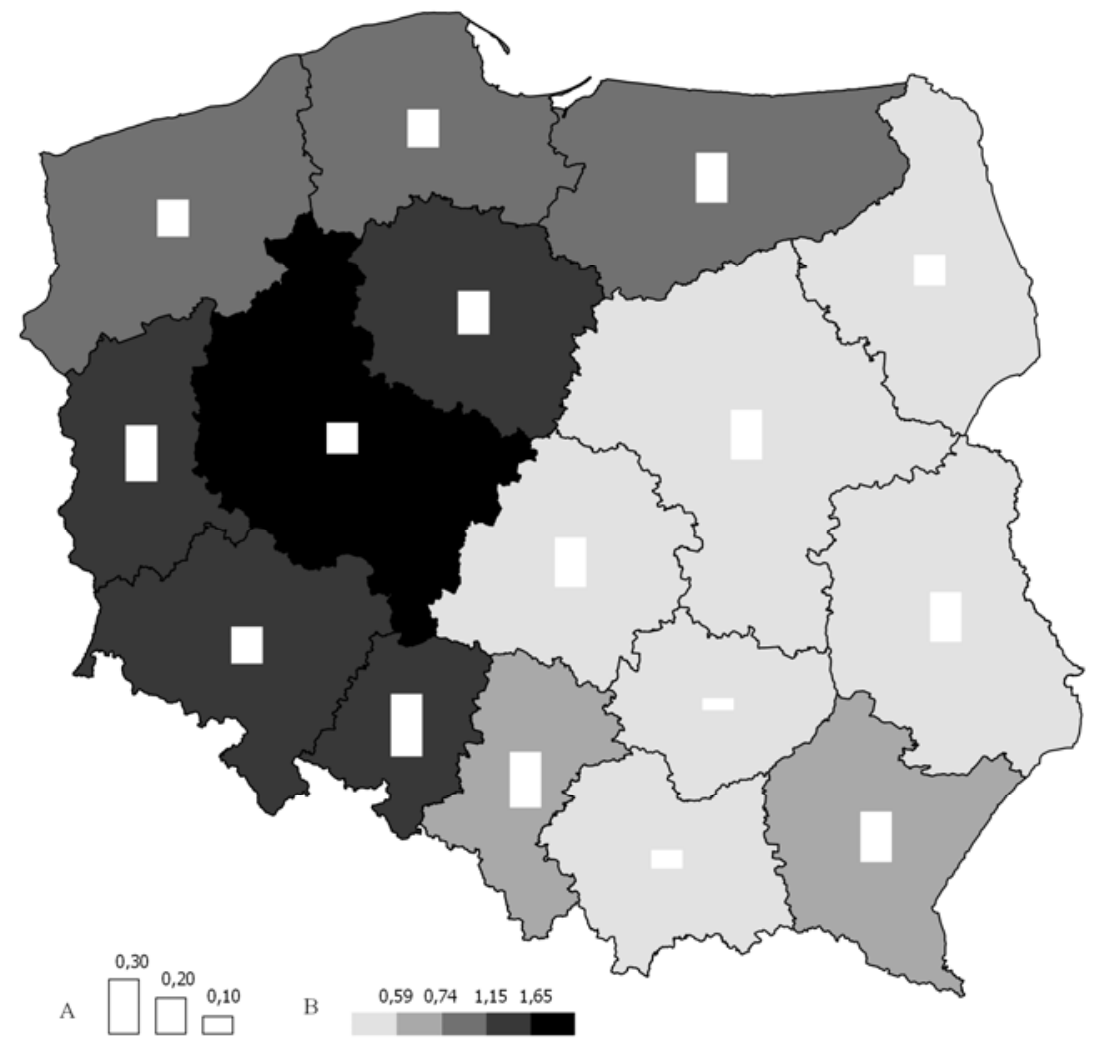

Rys. 1. Szkoły rolnicze a grupy producenckie w Polsce w 2014 roku

Objaśnienia: A - liczba szkół rolniczych na 10000 ha użytków rolniczych, B - liczba grup producenckich na 10000 ha użytków rolniczych

Źródło: opracowanie własne na podstawie stat.gov.pl/bdl, www.minrol.gov.pl

$\mathrm{O}$ ile szkoły rolnicze są w miarę równomiernie rozmieszczone na obszarze kraju, to w przypadku grup producentów rolnych występują duże dysproporcje. W 2014 roku najwięcej grup producenckich było zarejestrowanych w województwie wielkopolskim, gdzie na każde 10000 ha użytków rolnych przypadało prawie 2,4 grupy. Należy zauważyć, że w przypadku analizowania popularności pojedynczej grupy, istotnym elementem jest jej liczność, o tyle gdy rozpatrujemy popularność grup producenckich w ujęciu całościowym, ze względu na możliwość przynależności poszczególnych rolników do kilku organizacji jednocześnie i ochronę danych osobowych takie podejście obarczone jest błędem. $\mathrm{W}$ takiej sytuacji stosunkowo syntetyczną miarą popularności jest odniesienie liczby grup do powierzchni użytków rolniczych. Dużą popularnością grupy cieszyły się również w województwach: opolskim $(1,64)$, lubuskim $(1,62)$, dolnośląskim $(1,34)$ i kujawsko-pomorskim $(1,15)$. Występuje dość czytelny 
podział kraju na regiony o niskiej liczbie funkcjonujących grup producenckich, które występują głównie w południowo-wschodniej Polsce. Najmniej grup w 2014 roku działało w województwie świętokrzyskim i małopolskim, gdzie odpowiednio na każde 10000 UR przypadało zaledwie 0,27 i 0,28 grupy, co pokrywało się z najgorszym dostępem do szkół rolniczych. Mniejszą popularność grup producentów rolnych trudno jednak tłumaczyć gorszą dostępnością do wykształcenia rolniczego, gdyż w województwie wielkopolskim pomimo stosunkowo małej liczby szkół grup producenckich jest najwięcej w przeliczeniu na 10000 ha UR $(2,36)$. Występuje bardzo słaba zależność pomiędzy istnieniem szkół rolniczych a powstawaniem grup producentów rolnych, co potwierdza współczynnik korelacji, który jest w tym przypadku nieistotny statystycznie.

\section{Podstawa programowa a grupy producentów rolnych}

Oczekiwanie wpływu działalności szkół rolniczych w upowszechnianiu idei grup producentów rolnych może być realizowane pośrednio przez podniesienie wiedzy ogólnej wśród przyszłych rolników, którzy sami mogą zauważyć korzyści wynikające $\mathrm{z}$ przynależności do grupy. Zmiana podstawy programowej kształcenia w zawodach Rozporzadzeniem Ministra Edukacji Narodowej z 7 lutego 2012 roku (Dz.U., 2012, poz. 184), która miała na celu powiązanie wiedzy z praktyką umożliwiła szkołom bezpośrednią możliwość zaangażowania się $\mathrm{W}$ popularyzację idei grup producenckich. Uzyskana autonomia szkół w zakresie tworzenia i realizowania programów nauczania umożliwia realizację specjalnego przedmiotu poświęconego grupom producenckich. W odpowiedzi na zauważalną potrzebę przekazania treści $\mathrm{z}$ zakresu integracji poziomej producentów rolnych, Krajowe Centrum Edukacji Rolniczej w Brwinowie zaproponowało realizację przedmiotu „Spółdzielczość i grupy producentów w warunkach gospodarki rynkowej”. W 2014 roku przygotowano wzorcowy program nauczania tego przedmiotu obejmującego 30 godzin lekcyjnych. W trakcie jego trwania uczeń powinien nabyć szereg praktycznych umiejętności, m.in. potrafić zarejestrować grupę, opracować plan działalności grupy czy wniosek o wsparcie finansowe pochodzące ze środków Unii Europejskiej na działalność grupy producentów (Program nauczania... 2014). Przedmiot proponowany jest dla zawodów technik rolnik, agrobiznesu i ogrodnik. Przedstawiona przez KCER propozycja stanowi punkt wyjścia do przekazania informacji z zakresu tworzenia i funkcjonowania grup producenckich, jednak to od dobrej woli każdej szkoły zależy czy przedmiot będzie realizowany i w jakim zakresie. Komplementarnym elementem zaproponowanego programu nauczania było zorganizowanie w marcu 2014 roku przez KCER specjalnego seminarium przygotowującego kadry do realizacji przedmiotu. Zainteresowanie ze strony nauczycieli udziałem w seminarium było jednak niskie, gdyż uczestniczyło w nim zaledwie 45 nauczycieli z całego kraju. 


\section{Znajomość idei grup producenckich wśród uczniów szkół rolniczych}

Wyposażenie przyszłych rolników i kadr pracujących w obsłudze rolnictwa $\mathrm{w}$ wiedzę $\mathrm{z}$ zakresu tworzenia i funkcjonowania grup producenckich może stanowić jeden z najważniejszych czynników popularyzacji tej idei. Wydaje się, że jedynie przekonanie do integracji osób młodych, które są pozbawione złych doświadczeń polskiej spółdzielczości z przełomu lat 80 i 90 XX wieku może przyczynić się do powszechnej przynależności polskich rolników do grup producentów rolnych.

Realizacja badania ankietowego przeprowadzonego na grupie 185 respondentów dwóch szkół rolniczych z terenu województwa wielkopolskiego miała pozwolić określić stopień znajomości idei grup producenckich wśród uczniów. Należy zaznaczyć, że w szkołach, w których było realizowane badanie ankietowe nie realizowano specjalnego przedmiotu związanego z tematyką grup producenckich.

Respondenci byli bardzo niejednomyślni w zdefiniowaniu pojęcia grupy producenckiej. W opinii ponad 40\% uczniów, grupa jest zrzeszeniem rolników, którzy chcą wspólnie sprzedawać swoje produkty oraz razem zaopatrywać się w środki do produkcji rolnej (rys. 2). Skoncentrowanie się respondentów na traktowaniu grupy jako podmiotu pośredniczącego w sprzedaży produktów rolnych wydaje się logiczne, gdyż bardzo często to właśnie problem ze zbytem produktów rolnych był przyczyną powstania grupy, a w początkowym okresie funkcjonowania grupy przeważnie ograniczają zakres swej działalności do wspólnej sprzedaży. Badani nie wykazali jednak konsekwencji pomiędzy przyjmowaną definicją a korzyściami wynikającymi z przynależności do grupy, gdyż najwięcej, bo $21 \%$ twierdziło, że korzyścią są wspólne inwestycje, które w rzeczywistości są mało popularne (rys. 3). W opinii $20 \%$ respondentów najważniejszym profitem jest uzyskiwanie lepszej ceny za jednolite partie produktów. Niemniej zdania na temat korzyści $\mathrm{z}$ działalności grupowej były bardzo podzielone.

Ponad połowa ankietowanych (53\%) twierdziła, że nie zna żadnej grupy producentów działającej w swoje okolicy. Jednak wśród osób mających odmienne zdanie ponad $33 \%$ nie potrafiło wskazać żadnej konkretnej grupy. $\mathrm{Z}$ podaniem nazwy większy problem mieli uczniowie ze szkoły z powiatu ostrowskiego, spośród których zaledwie $14 \%$ podało nazwę. Respondenci przeważnie podawali nazwy najstarszych grup zarejestrowanych na obszarze powiatu, na terenie którego zlokalizowana jest szkoła, zdarzały się sporadyczne przypadki podawania nazw firm, które zajmują się pośrednictwem w obrocie płodami rolnymi, jednak nie są grupami producenckimi. Warto zauważyć, że ponad 50\% respondentów deklarowało, że posiada pośród rodziny lub znajomych osoby będące członkami jakiejś grupy producenckiej. 


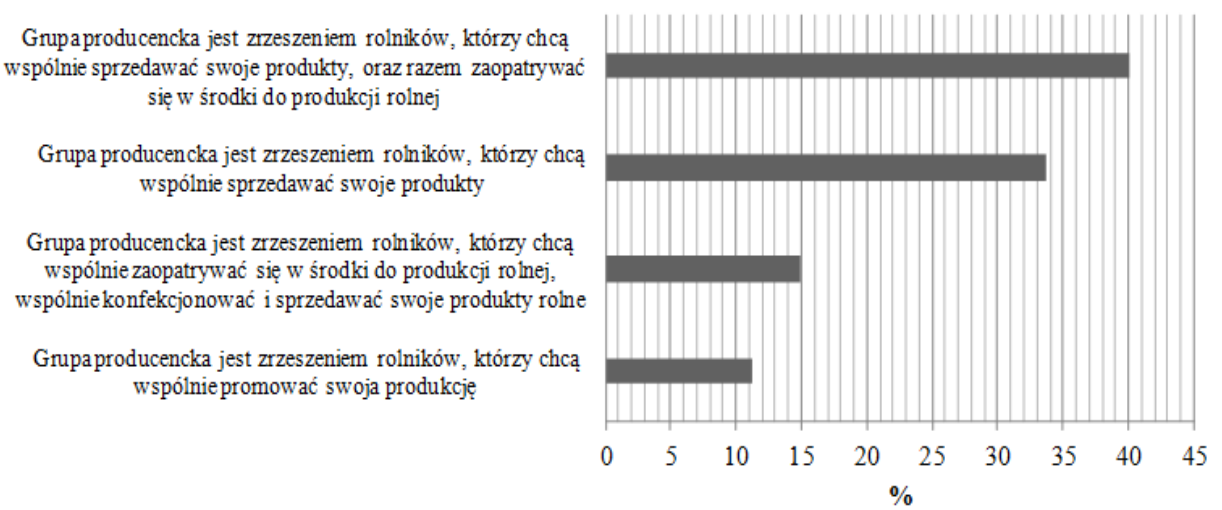

Rys. 2. Definicja grupy producentów rolnych wg uczniów szkół rolniczych Źródło: opracowanie własne na podstawie badań ankietowych

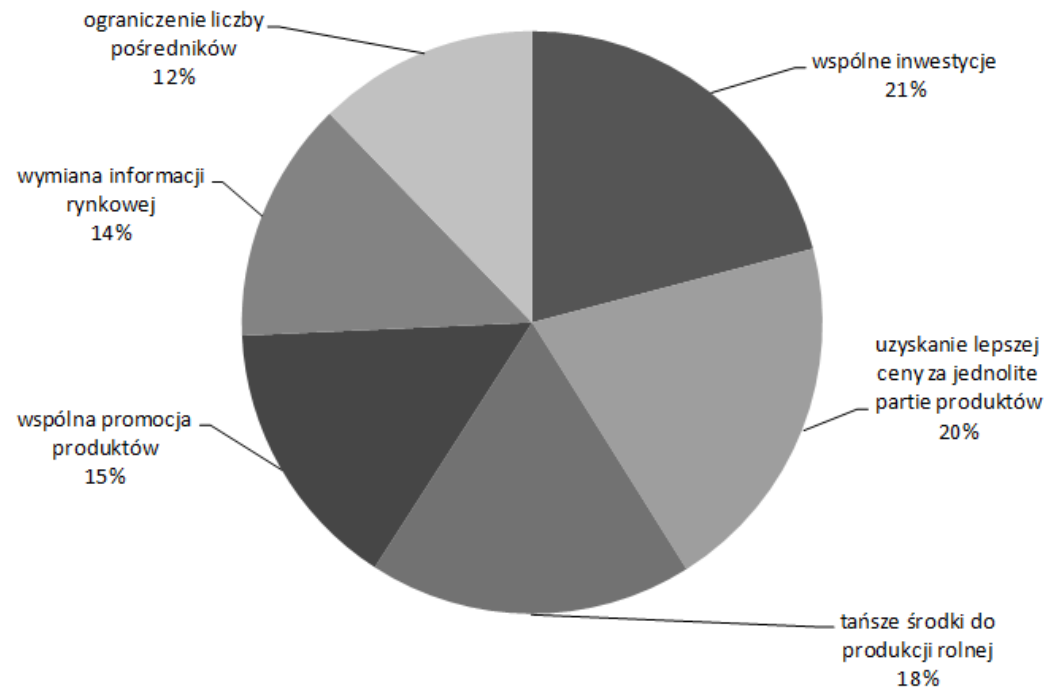

Rys. 3. Korzyści wynikające z przynależności do grupy producenckiej w ocenie uczniów szkół rolniczych

Źródło: opracowanie własne na podstawie badań ankietowych

Zdecydowana większość osób właśnie z tej frakcji (70\%) potrafiła wykazać się znajomością konkretnej grupy producenckiej.

Słaba znajomość tematyki grup producenckich została potwierdzona bardziej szczegółowymi pytaniami dotyczącymi funkcjonowania grup. Zaledwie 42\% respondentów twierdziło, że grupy producenckie mogą korzystać ze wsparcia w ramach Programu Rozwoju Obszarów Wiejskich 2007-2013, jednak tylko nieco ponad $10 \%$ potrafiło sprecyzować konkretne działanie. Żaden z respondentów nie potrafił wskazać miejsca rejestracji grupy producenckiej. Najbliżej 
prawidłowej odpowiedzi były osoby, które wskazały, że grupę rejestruje się w Krajowym Rejestrze Sądowym. Taka odpowiedź w pewnym sensie jest dobra, gdyż grupa ze względu na formę prawną podlega rejestracji w KRS jak każda firma, jednak status grupy producenckiej uzyskuje się dopiero po zarejestrowaniu jej w Urzędzie Marszałkowskim.

Pomimo nie realizowania $\mathrm{w}$ szkołach specjalnego przedmiotu dotyczącego integracji producentów rolnych, ponad $57 \%$ twierdziło, że w szkole mogą zapoznać się z tematyką grup producenckich. Najczęściej odbywa się to na lekcjach (76\%) lub wyjazdach studyjnych (22\%). Zdaniem większości uczniów (ponad 76\%) ich szkoła nie współpracuje z grupą producencką, np. przy organizacji praktyk zawodowych. Wśród mających odmienne zdanie, tylko $47 \%$ potrafiło wskazać konkretną grupę, z czego zdecydowana większość to uczniowie szkoły z powiatu krotoszyńskiego, którzy deklarowali współpracę z miejscową grupą producentów rolnych. Taka współpraca rzeczywiście jest podejmowana przy okazji organizowanego od 2013 roku Festiwalu Wieprzowiny na terenie powiatu.

\section{Podsumowanie}

Sieć szkół rolniczych, która jest w miarę równomiernie rozmieszczona na terenie kraju stanowi potencjał do kreowania przemian w rolnictwie i na obszarach wiejskich, w tym do upowszechniania idei grup producentów rolnych. Brak znaczącej zależności między istnieniem szkół rolniczych a powstawaniem grup producenckich sugeruje, że raczej nie są wykorzystywane do upowszechniania działań integracyjnych wśród rolników.

Znajomość idei grup producenckich wśród uczniów pozostawia wiele do życzenia, a posiadana wiedza jeśli jest, pochodzi raczej z form pozaszkolnych. Współpraca między szkołami a grupami producenckimi należy do wyjątków, a z relacji uczniów wynika, że ma raczej charakter epizodyczny.

Możliwość większej autonomii w kształtowaniu programu nauczania daje rzeczywiste podstawy do aktywnego propagowania grup producenckich wśród uczniów, wymaga to jednak dobrej woli ze strony szkól, a przede wszystkim ich merytorycznego przygotowania, co pozwoli na podniesienie znaczenia szkół rolniczych w rozwoju grup producenckich. Istniejące organizacje rolnicze, a przede wszystkim działające grupy producenckie powinny podjąć aktywną współpracę ze szkołami rolniczymi, z którymi mogą podzielić się praktycznymi doświadczeniami z zakresu funkcjonowania grup producenckich. 


\section{LITERATURA}

Dominiak J., 2012, Dostępność usług publicznych na terenie województwa wielkopolskiego, Poznań.

Hamerska I., Roczkowska-Chmaj S., 2008, Wykształcenie i wiek rolników a wskaźnik postępu naukowo-technicznego, „Inżynieria Rolnicza”, 11(109), Kraków, s. 75-82.

Kałuża H., Ginter A., 2014, Innowacje w gospodarstwach rolniczych młodych rolników, „Prace Naukowe Uniwersytetu Ekonomicznego we Wrocławiu”, 361, Wydawnictwo Uniwersytetu Ekonomicznego we Wrocławiu, Wrocław, s. 89-98.

Kania J., 2006, Znaczenie doradztwa $w$ rozwoju rolnictwa $i$ obszarów wiejskich, [w:] Miejsce doradztwa we wspieraniu rozwoju rolnictwa $i$ wsi na Kujawach i Pomorzu, K-PODR, Minikowo, s. 22-35.

Kania J., 2014, System wiedzy i informacji rolniczej w rolnictwie polskim, „Prace Naukowe Uniwersytetu Ekonomicznego we Wrocławiu", 360, Wydawnictwo Uniwersytetu Ekonomicznego we Wrocławiu, Wrocław, s. 55-62.

Kołoszko-Chomentowska Z., 2008, Wykształcenie ludności rolniczej jako determinanta rozwoju rolnictwa, ,Zeszyty Naukowe SGGW - Ekonomika i Organizacja Gospodarki Żywnościowej”, 67, Wydawnictwo SGGW, Warszawa, s. 79-86.

Krzyworzeka A., 2011, Funkcjonowanie wiedzy rolniczej, „E-mentor”, nr 3(40), Warszawa, s. 58-62.

Krzyżanowska K., 2000, Skuteczność upowszechniania postępu organizacyjnego $w$ rolnictwie - strategie doradcze, SGGW, Warszawa.

Program nauczania przedmiotu Spółdzielczość i grupy producentów $w$ warunkach gospodarki rynkowej, 2014, Krajowe Centrum Edukacji Rolniczej, Brwinów.

Rozporzadzenie Ministra Edukacji Narodowej z dnia 7 lutego 2012 roku w sprawie podstawy programowej ksztatcenia w zawodach (Dz.U., 2012, poz. 184).

Rozporzadzenie Ministra Rolnictwa i Rozwoju Wsi z dnia 17 stycznia 2012 roku w sprawie kwalifikacji rolniczych posiadanych przez osoby wykonujace działalność rolnicza (Dz.U., 2012, poz. 109).

Ustawa z dnia 7 września 1991 roku o systemie oświaty (Dz.U., 1991, nr 95, poz. 425).

Ustawa z dnia 15 września 2000 roku o grupach producentów rolnych i ich związach oraz o zmianie innych ustaw (Dz.U., nr 88, poz. 983 ze zm.).

Wasilewski K., 2011, System kształcenia rolniczego - stan i perspektywy, [w:] Domalewski J. (red.), Zadania i funkcje szkół rolniczych w Polsce, Warszawa, s. 33-55.

\section{Źródła internetowe}

stat.gov.pl/bdl (dostęp: 2.10.2014).

www.minrol.gov.pl (dostęp: 2.10.2014).

\section{KNOWLEDGE OF THE IDEA OF AGRICULTURAL PRODUCER GROUPS AMONG STUDENTS OF AGRICULTURAL SCHOOLS}

\footnotetext{
Abstract: The aim of this paper is identify the knowledge of the idea of agricultural producer groups among students of agricultural schools. Despite the large number of initiatives to support the development of producer groups, for both of a promotional or
} 
educational nature, integration among Polish farmers still is not popular. It was pointed out that the trend to increased integration of farmers younger and better educated, suggests that greater attention should be paid on the system of agricultural education. Relatively well-developed network of agricultural schools is the potential to promote the idea of producer groups. However, the study did not show direct correlation between the occurrence of the agricultural schools and the formation of producer groups. Despite the possibility of implementing by agricultural school educational module on the functioning of producer groups, knowledge of ideas among students is poor.

Key words: agricultural producer groups, agricultural schools, curriculum.

Mgr inż. Dawid Bała Zakład Gospodarki Żywnościowej i Wsi Instytut Geografii Społeczno-Ekonomicznej i Gospodarki Przestrzennej Wydział Nauk Geograficznych i Geologicznych Uniwersytet im. Adama Mickiewicza w Poznaniu 